\title{
Проблема сохранения национальной идентичности швейцарцев в условиях глобализации
}

(медиаметрический анализ)

Тамара Якова

Дарья Чуфтаева

Тема сохранения национальной идентичности занимает особое место в повестке дня швейцарских массмедиа и привлекает активное внимание интернетпользователей. В статье представлены результаты исследования запросов аудитории швейцарского сегмента Интернета по данной теме. Обработка статистических данных

и интерпретация результатов медиаметрического анализа проводилась на основе медиагеографического подхода, акцентирующего внимание на трансформации смыслов в пространстве и времени в процессе конструирования медиареальности.

Ключевые слова: национальная идентичность, швейцарские массмедиа, медиаметрический анализ, интернет-аудитория, медиагеографический подход.

DOI: 10.30547/mediaalmanah.6.2020.94106

@ Якова Тамара Сергеевна кандидат филологических наук, доцент кафедры зарубежной журналистики и литературы факультета журналистики МГУ имени М.В. Ломоносова, t-yakova@mail.ru

@ Чуфтаева Дарья Сергеевна

выпускница аспирантуры факультета журналистики МГУ имени М.В. Ломоносова, ведущая эфира «Русского радио Коми», dashchu@yandex.ru
Одним из негативных проявлений глобализации и связанных с ней интеграционных процессов, охвативших все сферы общественной жизни, является унификация культурных ценностей, что ведет к нивелированию национального своеобразия и потере национальной идентичности. Проблема сохранения национальной идентичности в условиях глобализации занимает важное место в российских и зарубежных массмедиа. Этой теме посвящен целый ряд исследований, проведенных учеными российских научных школ. Особое место среди них занимают работы, анализирующие роль массмедиа в конструировании национальной идентичности (Батырев, 2007; Николайчук, Якова, Янгляева, 2018), сохранении национальной идентичности россиян (Асташова, Булатова, Енина, Ильина и др., 2017; Елхова, 2017) и других народов (Мосягина, 2020; Прутцков, 2016; Кауганов, 2013), в региональной идентичности (Асташова, 2020; Якова, Янгляева, 2019). Эмпирическую базу исследования швейцарского кейса составили публикации массмедиа Швейцарии (2015-2020 гг.), материалы сайтов и порталов государственных структур Конфедерации (прежде всего ВАКОМ, курирующей вопросы государственной информационной политики), статистические данные поисковой системы Google Trends. Контент-анализ публикаций 
массмедиа стал базой для исследования темы в швейцарском сегменте Интернета (социальные сети Facebook, Instagram, Twitter и блоги Skyrock). Результаты анализа интерпретировались через призму медиагеографического подхода, в фокусе которого рассматривается динамика развития смыслов в пространстве и времени (Якова, Янгляева, 2019).

\section{Национальная идентичность швейцарцев: основные составляющие}

Швейцарское общество, полиэтническое и многоязычное (в Швейцарии четыре официальных языка ${ }^{1}$ и десятки диалектов), в течение веков формировавшее свою национальную идентичность, уделяет этой проблеме особое внимание: в последние годы тема перманентно обсуждается на разных дискуссионных платформах (от федерального парламента до общин) и активно освещается в массмедиа. Обеспокоенность швейцарцев проблемой сохранения своей национальной идентичности связана также и со стремительным ростом доли мигрантов среди граждан Конфедерации (к 2020 г. - более 30\%). Этнокультурные проблемы и вопросы, связанные с национальной идентичностью, в условиях глобализации актуализировались в еще большей степени - в швейцарских кантонах глобальное, будучи освоенным определенными национальными способами, проявляется в локальных формах. Проблема национальной идентичности швейцарцев тесно связана с историей страны. Процессы формирования Швейцарской Конфедерации как государства сопровождались продвижением общинной национальной идеи, заменившей представление об этнически и культурно однородной нации, поскольку в данном случае отсутствовали традиционные факторы национальной идентификации (язык, культура, традиции и др.). Сегодня Швейцарская Конфедерация определяет себя как объединение сосуществующих сообществ, а национальные связи обосновываются на различных уровнях идентификации со своей общиной, кантоном, языковой группой. Эта особенность многомерности связей внутри нации дополняется системой децентрализованного государственного строительства и является основой как регионального, так и национального самосознания швейцарцев, что и составляет главный стержень швейцарской национальной идентичности.

Кроме того, по мнению швейцарских историков, сочетание реальной истории и мифов составляет важную часть швейцарского национального самосознания и считается важным инструментарием для укрепления сплоченности сообщества даже в современном контексте. К примеру, миф о "клятве на Рютли», положившей начало Швейцарской Конфедерации², сегодня в сознании швейцарцев является основой для определения национальной идентичности. Можно также привести исторический факт о признании европейскими государствами «вечного нейтралитета» Швейцарии, не теряющий свою актуальность уже более двухсот лет. Представления об этих событиях являются важными составляющими швейцарского национального самосознания.

Особое значение имеет и исторически сложившееся административное деление страны: Швейцария - это федеративная парламентская республика, которая состоит из 20 кантонов и шести полукантонов, а также из 3000 общин. Каждый гражданин ассоциирует себя прежде всего с общиной, в которой он живет, а затем уже с кантоном и Конфедерацией.

\section{Информационная политика по сохранению национальной идентичности}

В Швейцарии, с ее политикой «вечного нейтралитета» и осторожного отношения к участию в международных сообществах ${ }^{4}$, на государственном уровне предпринимаются усилия по выработке новых механизмов интеграции и межкультурного 
взаимодействия между языковыми группами для достижения консолидации фрагментированного по этнокультурным признакам общества. Помимо конституционной поддержки языковых прав государство поддерживает политику мультикультурализма в сферах образования, просвещения и средств массовой коммуникации.

Правительство и парламент Швейцарской Конфедерации уделяют большое внимание вопросам сохранения национальной идентичности в своей повседневной деятельности. Контроль за соблюдением законодательных актов в этой сфере исполняют различные комиссии, в том числе и федеральный департамент ВАСОМ 5 . Еще одной правительственной структурой, курирующей вопросы национальной идентичности, является Федеральная миграционная комиссия, на сайте которой есть специальный раздел «Идентичность и национальные государства». В официальном обращении комиссии отмечено, что понятие национальной идентичности не ограничивается определением гражданства. Национальные государства стремятся создать национальную культуру, которая позволяет гражданам государства выглядеть как «культурно однородная» нация. Продвижение национального языка, системы образования и военной службы способствуют этой гомогенизации. Воспитание чувства сплоченностиб важно для разграничения общества с внешним миром и для возможности каждого его общества идентифицировать себя с ним. «Продвижение национальной идентичности играет центральную роль в создании швейцарского государства. Швейцария, как "нация согласия"7, не разделяет языки, но и не образует религиозную или однородную общину. Напротив, именно эта неоднородность, находящая свое выражение в многоязычии и федерализме, стала важным аспектом национальной культуры»8.

В 1998 г. Швейцария ратифицировала Рамочную конвенцию Совета Европы о защите национальных меньшинств. Соглашение предусматривает защиту меньшинств, например, странствующих (кочевников) или еврейских общин, а также поощрение и сохранение национальных языковых меньшинств. Этот документ имеет особое значение в условиях большого притока мигрантов в последнее десятилетие.

Особое внимание уделяется законодательному регулированию деятельности радиовещания и телевидения (особенно общественного телевидения SRG SSR (Schweizerische Radio- und Fernsehgesellschaft)), которое обязано учитывать особенности языковых регионов страны9.

\section{Тема сохранения национальной идентичности в массмедиа}

Современная Швейцария бережно относится к своему историческому и культурному наследию, стремясь сохранить единство страны и своеобразие ее отдельных регионов. Особую роль в этих процессах играют массмедиа.

В ходе исследования были проанализированы статьи качественных швейцарских газет за 2015-2020 гг., имеющих различную политическую ориентацию, а именно: Tages-Anzeiger - леволиберальную, Neue Züricher Zeitung - праволиберальную и Schweizerzeit - правую, консервативную. В соответствии со своей политической направленностью вышеназванные издания по-разному отражают и оценивают ежегодный приток мигрантов, трансляцию национального наследия современным поколениям, сохранение исторической памяти, но во всех публикациях поднимается вопрос сохранения национальной идентичности. Чаще других на страницах этих изданий в повестку дня включаются темы сохранения национальных идеалов и культурных традиций (в отношении всех языковых регионов страны).

Наиболее эффективным средством реализации государственной информационной политики выступаеттелевидение, 
которое представляет швейцарской аудитории мультикультурный опыт разных регионов страны и социальных групп, тем самым способствуя развитию интеграционных и коммуникативных процессов между представителями социума. В 2000 гг. общественное телевидение SRG SSR активно пропагандировало «швейцарскую идею» (idée suisse), фокусируясь на интеграции многоязычного общества и сохранении национальной идентичности 10 . Сегодня телерадиокомпания продолжает проводить политику мультикультурализма с учетом изменений в этнокультурном составе населения в связи с большим притоком мигрантов.

Феномен Швейцарской вещательной корпорации SRG SSR заключается в том, что она производит высококачественный контент на четырех официальных языках страны для девяти телеканалов и 14 радиостанций. Кроме того, корпорация представлена в мировом мультимедийном пространстве: международная информационная служба swissinfo.ch производит контент на десяти языках.

Швейцарский медиарынок разделен на сегменты по разным признакам, и прежде всего по языковому. Швейцарское телевидение и радио, качественная пресса, воскресные и бульварные издания, бесплатные газеты образуют единый сектор, который ориентирован в основном на аудиторию немецкоязычной (более 5 млн человек) и франкоязычной (более 1,5 млн человек) частей страны. Все остальные СМИ сегментированы по географическому (кантоны) и экономическому (отдельные издательские дома и конгломераты) признакам. Например, газеты и локальные радиостанции в италоязычном кантоне Тичино или в Граубюндене, где распространен романшский язык, имеют ограниченное распространение в связи с их языковой спецификой.

Тема сохранения национальной идентичности обсуждается в массмедиа разного уровня и масштаба, но чаще всего - в локальных изданиях (кантональных, муниципальных, общинных). В последнеедесятилетие в связи с увеличением числа мигрантов эта тема все больше привлекает внимание швейцарской общественности: в дискуссиях, которые проходят на платформах как традиционных, так и новых медиа, принимают участие представители многочисленных партий и общественных организаций.

\section{Исследование запросов интернет-аудитории}

В статье представлены результаты исследования данных поисковой системы Google Trends'11. Анализ запросов был проведен по словам-маркерам, определяющим понятие «национальная идентичность» и связанным с ним по семантике: «идентичность» (identität) (см. рис. 1), «швейцарская идентичность» (schweizer identität), «национальная идентичность» (nationale identität) (см. рис. 2), «швейцарскость» (swissness) (см. рис. 3, 4). Поскольку немецкий язык является лидирующим среди официальных языков Швейцарской Конфедерации и им владеют практически все жители страны, рассматривалась динамика немецкоязычных запросов, за исключением «швейцарскости», так как данный термин употребляется швейцарцами исключительно в англоязычном варианте.

Рассматривая данные по запросу «идентичность», мы можем наблюдать постепенный спад интереса к этой теме с 2004 г. по 2010 г., после чего популярность продолжает удерживаться на одинаково невысоком уровне до настоящего времени. Это можно объяснить развитием политических процессов в стране: лидирующая более пятнадцати лет в парламенте Швейцарская народная партия (Schweizerische Volkspartei), приоритетом которой является консервативная политика и защита национальных интересов страны, регулярно в своих предвыборных программах и на парламентских заседаниях провозглашает 


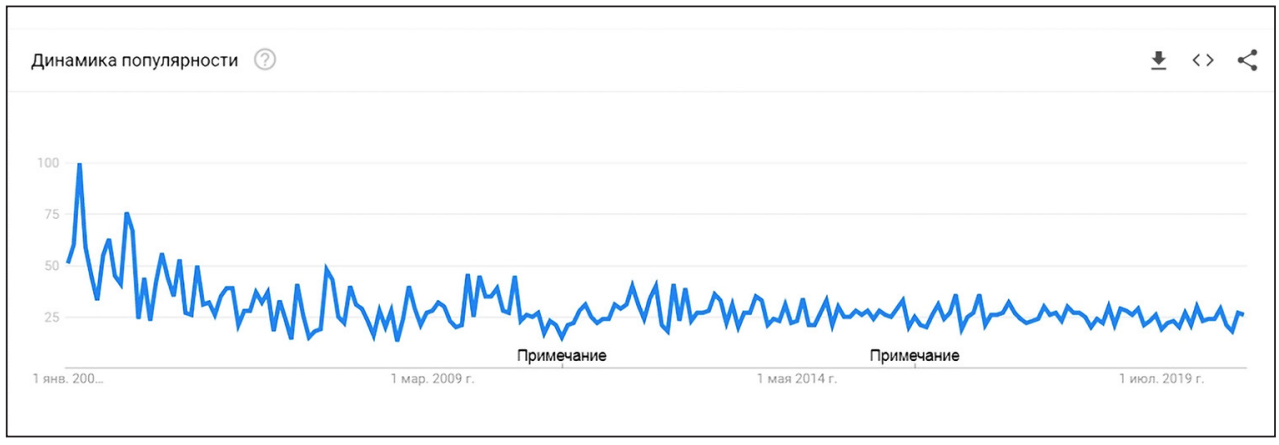

Рисунок 1. Динамика популярности запроса «identität» на территории Швейцарии в период с 01.01.2004 по 16.09.2020

Источник: данные запросов в Google Trends.

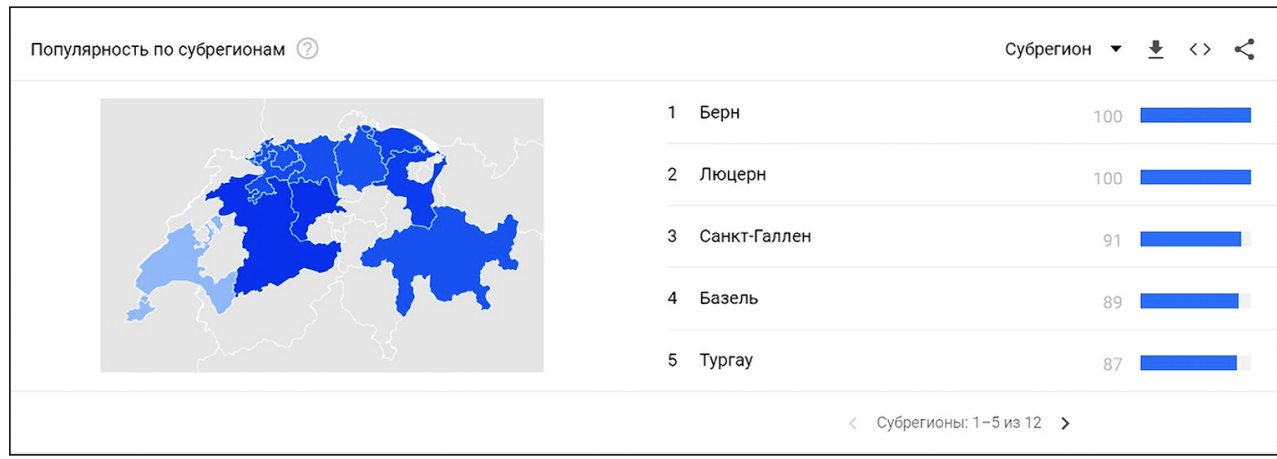

Рисунок 2. Распределение популярности запроса «identität» по кантонам Швейцарии в период с 01.01.2004 по 16.09.2020

Источник: данные запросов в Google Trends.

тезисы об уникальном пути Швейцарии и необходимости защитить внутренние интересы страны от внешнего, чаще всего европейского, влияния.

На внутриполитическом поле можно выявить различия: больший интерес ктеме демонстрирует население тех кантонов, в парламентах которых лидируют другие партии. Анализ данных по швейцарским регионам показывает, что наиболее популярен запрос «идентичность» в кантонах Берн, Люцерн, Санкт-Галлен, Базель и Тургау. В регионе Берн, в котором расположена одноименная столица федерации, лидирует Социал-демократическая партия Швейцарии (Sozialdemokratische Partei der Schweiz), которая выступает за полное вступление
Швейцарии в Европейский союз и более активное международное сотрудничество и влияние, несмотря на политику нейтралитета. Отметим, что в Люцерне большая часть населения разговаривает на немецком языке, а лидирующей в местном парламенте является социально-либеральная Христианско-демократическая народная партия (Christlich Demokratische Volkspartei), которая выступает за сохранение семейных и национальныхтрадиций, а также за умеренную миграционную политику, исключающую злоупотребление Швейцарией как политическим убежищем. В Санкт-Галлен и Тургау большинство мест в кантональных парламентах занимает консервативная Швейцарская народная партия, но в этих 


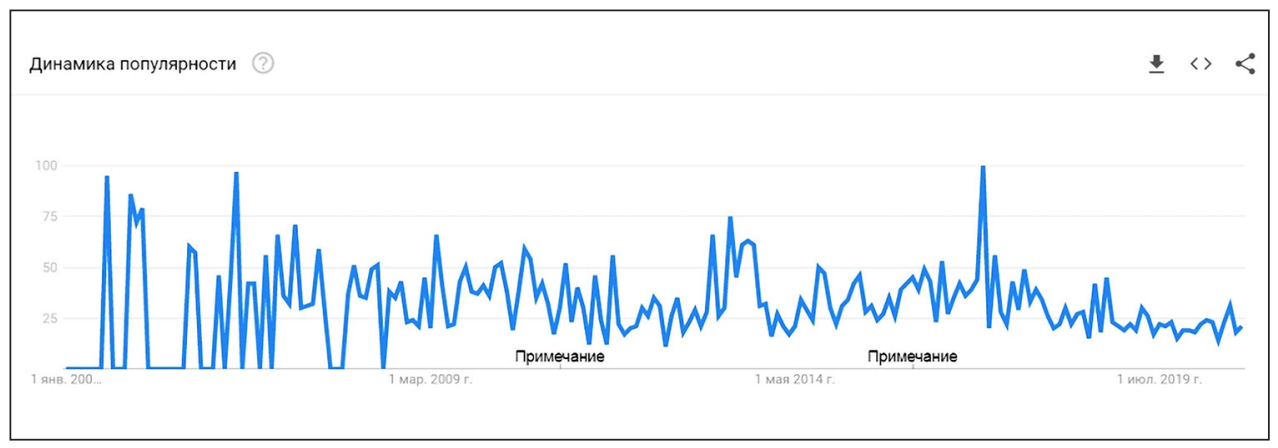

Рисунок 3. Динамика популярности запроса "swissness» на территории Швейцарии в период с 01.01.2004 по 16.09.2020

Источник: данные запросов в Google Trends.

регионах она наиболее активно лоббирует идеи сохранения уникальных особенностей и традиций в швейцарском обществе. Скорее всего, деятельность вышеназванных партий в местных парламентах стала одним из факторов интереса населения к теме «идентичность».

В ходе исследования были выделены более узкие варианты запросов в рамках заданной темы: «национальная идентичность» и "швейцарская идентичность». Несмотря на то, что временные рамки охватывали период с 2004 г. по настоящее время, результатов по данным запросам оказалось слишком мало для получения графиков их популярности. Как было описано выше, интерес к запросу «идентичность» был довольно низким последние десять лет, что не могло не стать причиной еще менее значительного проявления интереса к более определенным тематикам, связанным с национальностью и населением Швейцарии.

Больше информации Google Trends предоставляет по запросу «швейцарскость». Пик популярности данной темы наблюдался в 2004-2007 гг. Сам термин получил свое распространение в 1990 гг. и является своего рода знаком швейцарского качества, брендовой характеристикой товара, произведенного в Швейцарии. У большинства покупателей во всем мире примечание на упаковке товара «произведено в Швейцарии» или изображение белого гельветического креста на красном фоне ассоциируется с безупречным качеством (чем нередко пользовались и недобросовестные производители, предлагая товары под видом швейцарских $\left.{ }^{12}\right)$. Популярность запроса связана, скорее всего, с тем, что с начала нулевых компании постепенно стали представлять себя в сети Интернет с помощью регистрации доменных имен и собственных веб-сайтов. После 2007 г. наблюдается спад популярности, небольшие подъемы замечены лишь в 2010 г., когда швейцарская общественность начала обсуждать необходимость принятия закона, защищающего бренды, а также в 2013 г., когда данный закон был принят.

На рисунке 4 показаны регионы, наиболее часто использующие запрос "швейцарскость». Лидерами являются кантоны Берн, Санкт-Галлен и Цюрих (Берн - политический центр страны, Цюрих - экономический, Санкт-Галлен - крупный культурный и экономический регион восточной Швейцарии). Данные факторы, безусловно, повлияли на повышенный интерес к тематике «швейцаркость» в названных кантонах.

\section{Вопросы национальной идентичности в условиях пандемии}

В контексте данной темы особый интерес представляет анализ данных по 


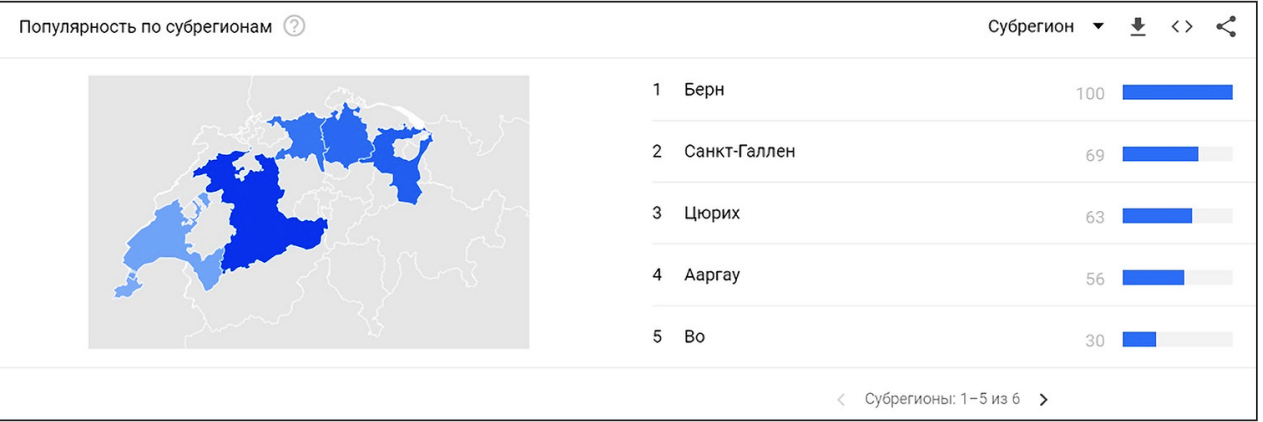

Рисунок 4. Распределение популярности запроса «swissness» по кантонам Швейцарии в период с 01.01.2004 по 16.09.2020

Источник: данные запросов в Google Trends.

Индексированное количество упоминаний

125

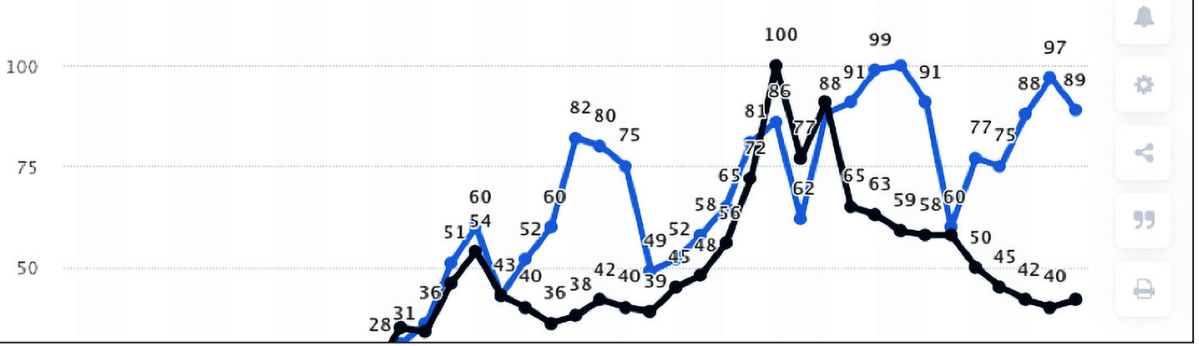

Рисунок 5. Внимание к темам «коронавирус» и «COVID-19» в сообщениях СMИ и в поиске Google в Швейцарии в 2020 г.

Источник: Statist (дата публикации: 09.04.2020). Режим доступа: https://www.statista.com/ statistics/1110530/coronavirus-covid-19-terms-media-google-search-switzerland/ (дата обращения: 30.07.2020).

запросам «коронавирус» и «COVID-19» за период с 10 февраля по 27 марта 2020 г. (в Google и в СМИ на территории Швейцарии) (см. рис. 5). Согласно данным, предоставленным агентством статистики Statista, выбор такого конкретного периода обусловлен наибольшим количеством запросов и упоминаний о коронавирусе в швейцарском сегменте Интернета. Рост интереса связан со следующими событиями: 25 февраля - первый зарегистрированный случай коронавирусной инфекции; 5 марта - сообщение о первом умершем от коронавируса в Швейцарии; 13 марта - Федеральный совет принял решение о принятии специальных мер по сдерживанию распространения вируса в стране ${ }^{13}$. Что касается динамики популярности темы, то решение о специальных мерах от 13 марта вызвало наибольший рост интереса пользователей Google. После 16 марта количество запросов о заболевании снова сократилось, при этом количество сообщений СМИ о коронавирусе (COVID-19) достигло своего пика к 19 марта. Стоит отметить, что количество запросов пользователей и упоминаний в СМИ значительно разнится - информационный всплеск влияет на повышение интереса населения только в краткосрочный период, во время 


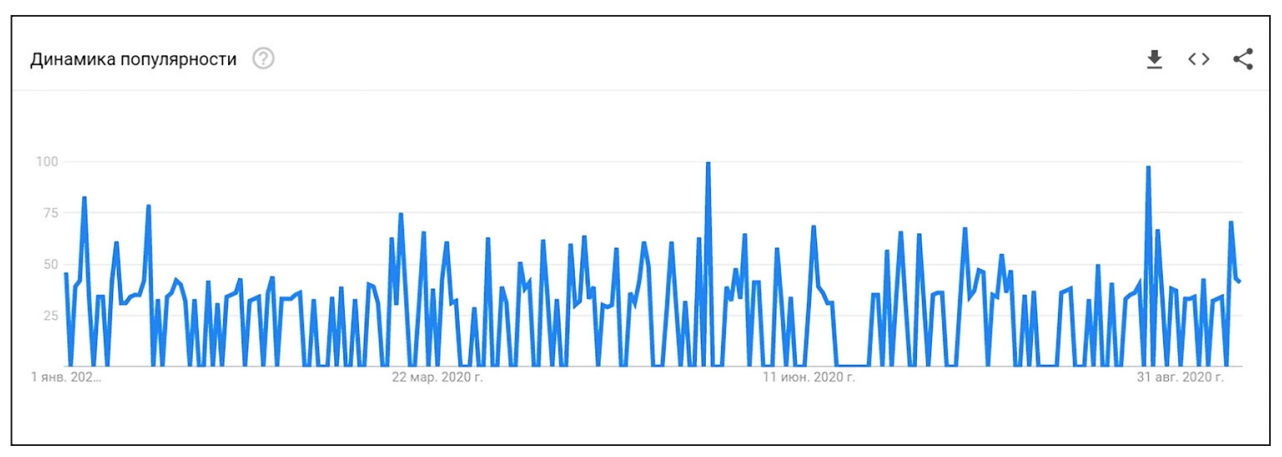

Рисунок 6. Динамика популярности запроса «identität» на территории Швейцарии в период с 01.01.2020 по 16.09.2020

Источник: данные запросов в Google Trends.

наиболее значимых и резонансных для общества событий.

Обратимся к данным Google Trends, позволяющим нам проследить динамику популярности рассмотренных ранее запросов «идентичность» (см. рис. 6) и «швейцарскость» (см. рис. 7,8$)$ в период пандемии: с января по сентябрь 2020 г. Согласно динамике популярности запросов, в течение девяти месяцев интерес к теме «идентичность» был на довольно высоком уровне. При этом можно наблюдать небольшой подъем популярности в разные периоды, как, например, в начале января 2020 г. (а именно, 4 и 19 января), также 13 марта, что, вероятнее всего, связано с принятием мер по COVID- 19, как уже было описано выше. Следующий подъем отмечен 19 мая, в этот день проходило всенародное голосование по нескольким вопросам: принятие Федерального закона о налоговой реформе $^{14}$ и директивы EC по контролю за огнестрельным оружием от 2017 г..$^{15}$ Кроме того, в данный период было зарегистрировано минимальное количество зараженных коронавирусом, что также позволило частично переключить информационную повестку в другое русло. Последний всплеск популярности запроса «идентичность» зафиксирован 24 августа, что может быть связано с резким ростом числа заболевших коронавирусом, начавшимся с середины августа ${ }^{16}$.
Что же касается запросов "швейцарская идентичность» и "национальная идентичность», то, как и в случае, где временной отрезок охватывал период с 2004 г. по настоящее время, в краткосрочном периоде запросов пользователей оказалось очень мало для формирования графиков динамики.

Рисунок 7 отражает популярность запроса "швейцаркость»" в течение 2020 г. Кроме отдельных пиков популярности в начале январе и в начале февраля уровень популярности оставался на среднем уровне, даже в самый активный период распространения коронавируса - с февраля по май. Что касается регионов, где данный запрос был наиболее популярен, то их рейтинг лишь подтверждает высказанную нами выше гипотезу, так как Берн, Санкт-Галлен, Женева, Цюрих и Ааргау являются экономически важными кантонами, где расположены крупнейшие предприятия и компании страны (см. рис. 8).

\section{Вопросы взаимодействия и доверия в условиях пандемии}

Начавшаяся в конце 2019 г. и продолжающаяся сегодня пандемия коронавируса (COVID-19) затронула в глобальном масштабе все общественные сферы. Большинство социологических исследований в период пандемии были сфокусированы на 


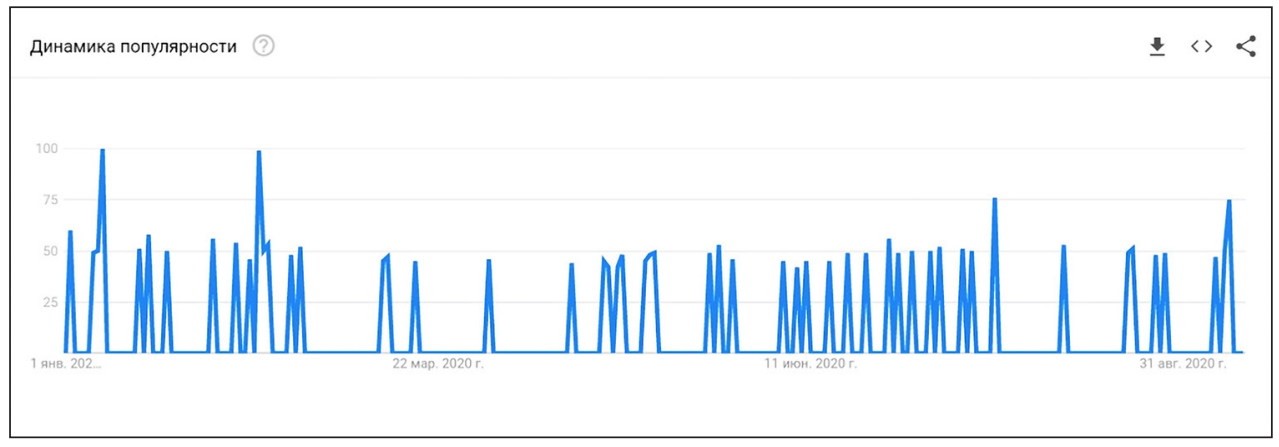

Рисунок 7. Динамика популярности запроса "swissness» на территории Швейцарии в период с 01.01.2020 по 16.09.2020

Источник: данные запросов в Google Trends.

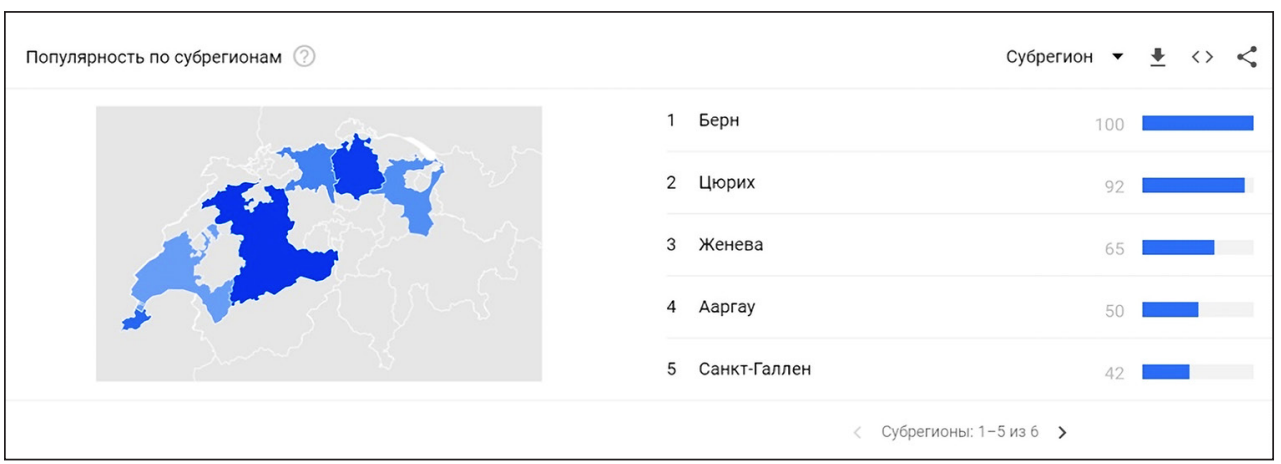

Рисунок 8. Распределение популярности запроса «swissness» по кантонам Швейцарии в период с 01.01.2020 по 16.09.2020

Источник: данные запросов в Google Trends.

медицинской и экономической тематике, но проводились и опросы, непосредственно касающиеся социальной сферы Швейцарии.

Первый опрос, проведенный социологическим агентством Statista, затрагивает социальный фактор, а именно, каким образом респонденты оценивают коммуникацию друг с другом в условиях пандемии (см. рис. 9). В ходе анкетирования была возможность выбирать несколько вариантов ответов. Большинство опрошенных охарактеризовали взаимодействие как проявление солидарности (62\% от общего числа респондентов) и дружественности (45\%). Значительно меньшая часть выбрала такие пункты, как эгоистичность (26\%) и недоверие (24\%). Учитывая то, что опрос был проведен в апреле 2020 г., то есть в самый пик распространения коронавируса в большинстве стран мира, когда информационная повестка была очень напряженная и тревожная, полученные результаты стали неожиданными: большая часть опрошенных в Швейцарии позитивно оценили взаимодействие внутри своего общества.

Эпидемия коронавируса в том числе повлияла на отношение населения к политическому руководству своей страны (см. рис. 10), так как во всем мире люди внимательно следили, какие шаги предпринимает их правительство для урегулирования эпидемиологической обстановки 


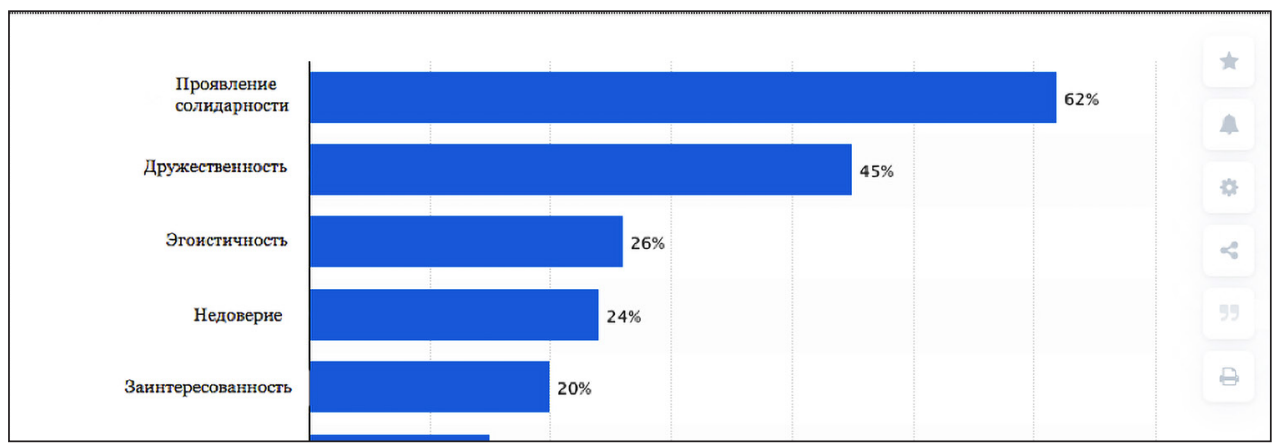

Рисунок 9. Как вы воспринимаете взаимодействие между людьми в текущей ситуации? Источник: Statista. Режим доступа: https://www.statista.com/statistics/1110498/coronaviruscovid-19-social-interactions-influence-switzerland/ (дата обращения: 30.07.2020).

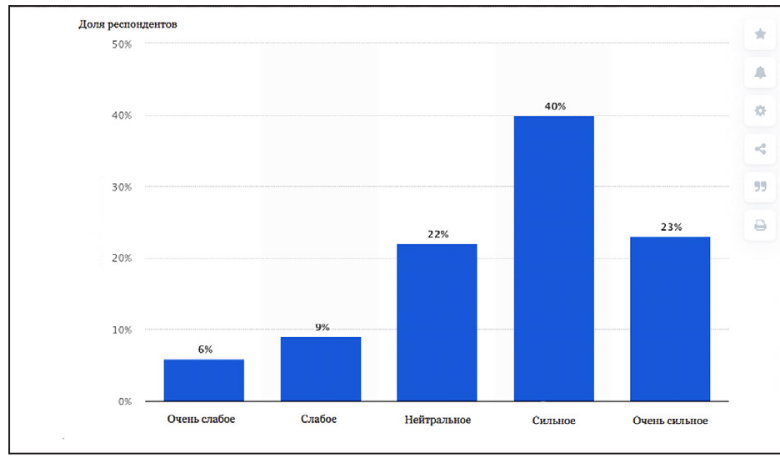

Рисунок 10. Насколько сильно ваше доверие к политическому руководству в плане борьбы с кризисом коронавируса (COVID-19)?

Источник: Statista. Режим доступа: https://www.statista.com/statistics/1110201/ coronavirus-covid-19-political-leadership-trust-switzerland/ (дата обращения: 30.07.2020).

и насколько эффективен их план по выходу из кризисной ситуации. В связи с этим были проанализированы данные по степени доверия швейцарского населения к своему политическому руководству в период борьбы с пандемией. Большинство опрошенных выбрали степени доверия «сильное» (40\%) и «очень сильное» (23\%); меньшая доля респондентов предпочла уровни доверия «слабое» (9\%) и «очень слабое» (6\%).

Данный опрос в совокупности с предыдущим создает позитивное впечатление об обстановке внутри Швейцарии в условиях пандемии и о настроениях, превалирующих в обществе в этот напряженный период. Анализ публикаций швейцарских массмедиа (онлайн-версий качественных изданий и текстов передач общественного телевидения) за последние пять лет продемонстрировал, что вопросам сохранения национальной идентичности уделяется большое внимание: все исследованные средства массовой информации поднимают различные аспекты данной темы в зависимости от их политической ориентации и интересов аудитории. Контент-анализ медиатекстов в пространственно-временной системе координат выявил заметный рост количества публикаций в течение исследуемого периода и плавную миграцию данной проблематики из региональных изданий в локальные (кантональные, муниципальные, 
общинные). В повестке дня ведущих немецкоязычных изданий, аудитория которых составляет более 70\% населения страны, чаще других обсуждаются проблемы сохранения национальных идеалов и культурных традиций в отношении всех языковых регионов в контексте увеличивающегося притока мигрантов и изменений в этнокультурном составе населения. Тема сохранения национальной идентичности наиболее масштабно и глубоко освещается в программах общественного телевидения SRG SSR, представляющих широкой аудитории мультикультурный опыт разных регионов страны.

\section{Выводы}

Медиаметрическое исследование швейцарского сегмента Интернета выявило, что интерес к теме национальной идентичности в течение последних лет (как и в предыдущее десятилетие) проявляется аудиторией на одинаково невысоком уровне, что связано с политическими процессами в стране и консервативной политикой правящей коалиции (с лидерством Швейцарской народной партии), приоритетом которой является защита национальных интересов от внешнего (прежде всего европейского) влияния. Различия в степени популярности темы в географическом разрезе связаны с деятельностью политических партий в разных кантонах: внимание аудитории привлекают политические дебаты по вопросам национальной идентичности, инициируемые Социал-демократической партией Швейцарии и Христианско-демократической народной партией.

В течение нескольких месяцев 2020 г. тема национальной идентичности обсуждается в швейцарских массмедиа в контексте многочисленных проблем, вызванных эпидемией коронавируса (COVID-19). Динамика популярности запросов в Google Trends в течение девяти месяцев текущего года свидетельствует о том, что интерес швейцарской аудитории растет, что связано с трансформациями в различных сферах общественной жизни. Опасность для здоровья и жизни людей, сохраняющаяся продолжительное время, оказывает влияние не только на экономику, политику, культуру, но и на сам образ жизни людей. Возможно предположить, что глобальные и локальные процессы, вызванные пандемией, окажут существенное влияние на представления швейцарцев о себе и о мире.

\section{Примечания}

1 Три языка (немецкий, французский и итальянский) имеют статус официальных, ретороманский (или романшский) в таком качестве используется только в одной области страны - кантоне Граубюнден. На немецком говорят 64,1\% населения страны, на французском - 22,7\%, на итальянском - 8,4\%, на ретороманском - 0,6\%. (См.: Швейцария: цифры и факты. Режим доступа: https://www.s-ge.com/sites/default/ files/publication/free/ihb-01-switzerland-facts-and-figures-in-russian-s-ge-2018-07. pdf (дата обращения: 20.07.2020)).

2 Начало истории швейцарского государства было положено 1 августа 1291 г., когда на лугу Рютли на берегу Фирвальдштетского озера три кантона - Швиц, Ури и Унтервальден - подписали договор о союзе и взаимной поддержке в борьбе с внешними врагами. Так называемая «Клятва на Лугу Рютли», а также «Союзная грамота» (Der Bundesbrief), датированная 1 августа 1291 г., с конца XIXв. рассматриваются в швейцарской мифологии как первый шаг на пути к формированию современной швейцарской нации. По случаю 600-летия данного события заключенное в XIX в. соглашение перевели в ранг учредительного документа Швейцарского союза. 
3 «Вечный нейтралитет» закреплен в Парижском мирном договоре 1815 г. по итогам Венского конгресса.

4 Швейцария не является членом Европейского союза, а в ООН вступила только в 2002 г. после неоднократных обсуждений этого вопроса на общенациональных референдумах; не входит в военно-политические коалиции и военные блоки.

5 Федеральное управление связи (ВАКОМ) выполняет задачи в области средств массовой информации, телекоммуникационной и почтовой связи, а также информационного общества в Швейцарии; обеспечивает стабильную коммуникационную инфраструктуру в стране и координирует реализацию стратегии «Цифровая Швейцария».

6 В документах Федеральной миграционной комиссии Швейцарской Конфедерации используется понятие «Мы-чувства» (Wir-Gefühl), которое в немецком языке обозначает чувство общности или сплоченности. "Сплоченность» (от лат. cohaerere) - термин из области социальной психологии и групповых процессов, описывает условия, при которых индивид видит себя вынужденным быть или оставаться членом группы в течение длительного времени.

7 Нем. «Willensnation» (пер. авт.).

8 Eidgenössische Migrationskommission. Identität und Nationalstaaten. Режим доступа: https://www.ekm.admin.ch/ekm/de/home/identitaet--zusammenhalt/identitaet/ident_ natstaaten.html (дата обращения: 10.07.2020).

9 Деятельность общественной радиотелекомпании SRG SSR регулируется федеральным законом «О радио- и телевизионном вещании» (2006 г.) и статьей 93 Конституции Швейцарской Конфедерации.

10 C 1999 по 2011 г. в названии медиакорпорации присутствовало словосочетание «швейцарская идея» - «SRG SSR idée suisse».

11 Google Trends - web-приложение, основанное на данных поисковой системы Google, которое показывает, как часто определенный термин ищут по отношению к общему объему поисковых запросов в различных регионах мира и на различных языках.

12 С 2017 г. после продолжительных дебатов в течение многих лет вступил в силу так называемый закон "swissness», защищающий швейцарскую экономику от нечестной конкуренции и запрещающий использовать швейцарский герб или информацию о том, что товар произведен в Швейцарии (Swiss Made), производителям, которые никак не связаны с данной страной.

13 Statista. Режим доступа: https://www.statista.com/statistics/1110530/coronaviruscovid-19-terms-media-google-search-switzerland/ (дата обращения: 30.07.2020).

14 Одним из основных пунктов реформирования стало предложение парламента упразднить налоговые привилегии для компаний, работающих на международном уровне.

15 Так как Швейцария не является членом ЕС, она может по собственному решению принимать правила действующих директив на территории своей страны.

16 Статистика по COVID-19 от Министерства здравоохранения Швейцарии. Режим доступа: https://covid-19-schweiz.bagapps.ch/de-2.html (дата обращения: 16.09.2020).

\section{Библиография}

Асташова О.И. Конструирование региональной идентичности в медиадискурсе: опыт сравнительного анализа // Политическая лингвистика. 2020. № 2 (80). С. 120-133. DOI 10.26170/pl20-02-13

Асташова О.И., Булатова Э.В., Енина Л.В., Ильина О.В. и др. Проблемы конструирования идентичности россиян в дискурсе СМИ под влиянием концепта «информационная война» / под ред. Э.В. Чепкиной. М.: Екатеринбург: Кабинетный ученый, 2017. 
Батырев Д.Н. Дискурс национальной идентичности в эпоху глобализации // Гуманитарные и социально-гуманитарные науки. 2007. № 4 (35). С. 10-14. Режим доступа: https://www.elibrary.ru/item.asp?id=12159729 (дата обращения: 03.09.2020).

Елхова О.И. Сохранение российской национальной идентичности в информационном мире // Вестн. Башкирск. ун-та. 2017. Т. 22. № 2. С. 551-554. Режим доступа: https://cyberleninka.ru/article/n/sohranenie-rossiyskoy-natsionalnoy-identichnosti-vinformatsionnom-mire-1/viewer (дата обращения: 30.08.2020).

Кауганов Е.Л. Дискурс национальной идентичности в послевоенной Германии // Очерки о европейской идентичности и многокультурности / под ред. М.Ю. Мартыновой. М.: ИЭА РАН, 2013. С. 11-73. Режим доступа: http://static.iea.ras.ru/books/Ocherki_ identichnosti_Martynova.pdf (дата обращения: 03.09.2020).

Мосягина М.С. Национальная идентичность и ее вербальное отражение в англоязычном медиадискурсе // Вестн. Самарск. ун-та. 2020. Т. 26. № 2. С. 169-175.

Николайчук И.А., Янгляева М.М., Якова Т.С. Национальная идентичность как морфоскульптура и фактор ментального общественного ландшафта в контексте национальной безопасности. Медиагеографический подход // Социально-гуманитарные знания. 2018. № 12. С. 141-157.

Прутцков Г.В. Проблема каталонской национальной идентичности на страницах газет «Ла Ренайшенса» и «Ла Вангуардиа» в конце XIX - начале XX вв. // МедиаАльманах. 2016. № 1. С. 63-68.

Якова Т.С., Янгляева М.М. Роль массмедиа в конструировании региональной идентичности: медиагеографические подходы // Вопросы теории и практики журналистики. 2019. Т. 8. № 3. С. 485-496. 